\title{
Research on the School-Enterprise Cooperation and the Training of Applied Talents in Music Performance of Applied Marine University
}

\author{
Jia ZHU \\ College of Art and Creativity \\ Hainan Tropical Ocean University \\ Sanya, China \\ E-mail: zhujia1217@126.com
}

\begin{abstract}
The paper analyzes the importance and feasibility of the process of school-enterprise cooperation by combining the regional characteristics and regional culture of Hainan International Tourism Island University, and puts forward some suggestions to make some suggestions on the development of Hainan International Tourism Island, Hope that colleges and universities can continue to explore the connotation and significance of school-enterprise cooperation, strengthen the school-enterprise cooperation research efforts and practical attempts to improve the ability of school-enterprise cooperation, the establishment of school-enterprise cooperation more possibilities and space, so that colleges and universities in the face of opportunities and Challenging more benign development.
\end{abstract}

Keywords-applied Talents, music performance, teaching Reform, talent development

\section{INTRODUCTION}

At present, the local colleges and universities in the music performance professionals face some difficulties, compared with the professional music institutions, sound professional students of the overall quality and practical ability is often relatively weak, ordinary local colleges and universities as a large number of music By the music professional start school, teachers and teaching in the inertia of the "music model", a single teaching methods, teaching evaluation standards exist bias, performance and practical ability of weak and so on. This relatively narrow education and teaching model, to a certain extent, caused the ordinary local college music performance students in the comprehensive ability and employment market and professional music institutions compared to graduates in the slightly trend, but also makes the current music performances Professional education and teaching drawbacks become increasingly prominent. And the combination of production and research, school-enterprise cooperation school road, so that schools and enterprises of two different educational environment and the efficient integration of educational resources to cultivate a comprehensive quality and performance talents, to promote the local university education market, Socialization, improve the relevance and effectiveness of education and teaching. Therefore, it is of great social significance and practical significance to study the cooperative mode of schoolenterprise cooperation for the application of professional talents in local university music performance.

\section{FOREIGN AND DOMESTIC UNIVERSITY MUSIC PERFORMANCE PROFESSIONAL DEVELOPMENT}

Looking at foreign music education, are combined with its culture with regional adaptation characteristics, not suitable for our original copy. American music education is compatible with the cultural characteristics of the formation of "multi-mode" of the music education system, Kodalai, Orff, Dahl Keluozu three kinds of education law mixed, pavilions, so that the United States music education presented to develop Students to "creative" as the dominant ideology of the characteristics of music education; Russia to take a strict, systematic, high-intensity of a single professional training model, the implementation of the master system, to cultivate music elite talent for education; Japanese music education to emphasize groupism Consciousness of collective music activities as the dominant ideology, attention to the collective chorus, play music activities, chorus, ensemble and other collective performances of the art of music is generally high, with the Japanese "soul spirit" national culture closely integrated with educational characteristics.

At present, many comprehensive universities and higher normal universities have also set up music professional. Through the current research on the training objectives and teaching modes of music performance in higher normal colleges, it is found that the development of music performance is in an embarrassing situation. Whether it is training objectives or teaching model, focusing on the students practical skills and practical ability to cultivate, so that students master the professional theoretical knowledge on the basis of master hands, brain, take the initiative to think and solve problems, learning content diversity The need for professionalism to reduce, making this mode of student professional skills, but hard. Which led to the students in the employment process of resistance, there cannot be as normal as the students directly into the teaching positions, but also because of the general level of performance and cannot be favored by professional groups and other serious problems. In contrast, some vocational 
colleges have done better in this respect, because of the different nature of running a school, so in the schoolenterprise cooperation and application-oriented personnel training has obvious advantages, but the training of talent level and ordinary colleges and universities are different, Therefore, in the ordinary local university music performance professional training should not only learn from all the innovation and the difference, the formation of longterm school management mechanism, and the valuable experience of the education system model.

\section{THE SIGNIFICANCE OF SCHOOL - ENTERPRISE COOPERATION}

\section{A. From the Angle of University}

With the establishment of music performances throughout the country more and more colleges and universities, music professional generally mostly classroomcentered model of training, and this talent training model with the development of society has become increasingly unable to adapt to the various employers Demand, especially in Hainan International Tourism Island, with the rapid development of economic and cultural industries, the demand for music talent gradually increased. Through the combination of the new training direction of music performance professional and the employment needs of international tourism island, we can realize the personnel training mode of university personnel training and regional culture linkage, integrate all kinds of teaching resources, reform the curriculum structure, train the music performance talents And Hainan international tourism island regional culture integration, and strengthen the performance of music talent practice, to explore a solid foundation, to adapt to a wider, practical application of strong application of technical music performance professionals in the new path, this path is also Is the international tourism island of Hainan, many colleges and universities of personnel training and school strategic development goals.

The setting of the professional direction is the prerequisite for cultivating the talents needed by the market and improving the employment rate of the students. Close to the market to meet the needs of employers on the needs of talent is also an important basis for professional orientation, colleges and universities as an important base for the transport of talent, should pay attention to the establishment of a joint supply and demand with the employer model, which requires from the professional, , "Combination of work and study, school-enterprise cooperation" allows the teaching unit through the employer flexible and accurate understanding of the market supply and demand, the employer will be the market demand information feedback to the teaching unit, so that the teaching unit can flexibly according to market demand to open Curriculum, set up professional and personnel training, and according to the social needs of talent situation, broaden professional development, improve professional construction and break through the development of disciplines.

\section{B. From The Angle of Student}

Students in the school is not just learning the theoretical knowledge, through the "school-enterprise combination" so that students in the school set the correct direction of the course to feel the fun of different courses in the "double teacher" teachers learn more Knowledge and skills, in the enterprise practice in the correct design of their own career planning, to master a variety of skills to adapt to social survival; only through this cooperation in order to allow students to learn from, in the intense employment pressure to stop their feet. Compared with the academic research colleges and universities, the application of technical colleges and universities is more concerned with the practical ability of operation, more practical and practical, so colleges and universities must strengthen the practice of education and professional ability to cultivate, and to achieve this goal must be able to meet Students need to build a "stage" as the core of the practice of teaching environment, that is, "the second classroom" is to cultivate music performance professional unity and cooperation, innovative talents, with a comprehensive practical performance talent, Such as the second class of Hainan Tropical Ocean University Music Performing Arts, with popular music groups, Western instruments, folk instruments, choirs, dance troupes and other practical groups, students through the "second classroom" comprehensive study practice Knowledge and use to stage performances, creation. "The combination of work and study, school-enterprise cooperation," the most direct way is to enterprises as an internship base, students in a real work platform, learning in line with social development, close to the market application capacity. From the professional aspects of music, students through the internship to the outside school, you can complete in the school cannot complete a variety of practical courses, such as music performance talent to the performance company can be a variety of occasions through the activities of the accumulation of stage experience, summed up self- Design planning career and so on. "School-enterprise cooperation" is the main way to cultivate students' good professional ethics, professional skills and work style. It is an important bridge for students to move from class to employment and occupation.

\section{From The Angle of Enterprise}

Enterprise survival and development of the key is the construction of the contingent of personnel, the music industry is also the case, if the lack of appropriate personnel, cannot survive for their own survival and efficiency, cannot improve their competitiveness. Enterprises and schools through cooperation in this cooperation can be a lot of the introduction of talents, can be more self-strengthening team. Hainan International Tourism Island has a lot of corporate business publicity on the performance of music professionals are gradually increased, all kinds of diet, life, consumption and other tertiary industry enterprises, companies, in their own product promotion, packaging pains, often recruited Some of the graduates of the arts, these graduates began to do simple grass-roots work in the unit, but every business culture and entertainment, product promotion and other 
activities, those who have the ability to organize the organization, because of the activities of the organization, The rehearsal work stands out. Secular culture on the music performance professionals are more demand, especially in the social entertainment industry, such as shopping malls, corporate celebrations, wedding and other secular culture, the rise of these enterprises need to compete in the industry and do a good job, The music performance talent have a more comprehensive requirements, so "school-enterprise combination" for their development has a very big advantage.

\section{COUNTERMEASURES AND SugGeStions ON "PROFESSIONAL COOPERATION BETWEEN SCHOOL AND ENTERPRISE" IN MUSIC PERFORMANCE}

The arts and cultural market is a multi-level, structured art talent supply and demand field. In the school-enterprise cooperation, we first identify different levels of art from the leading, pilot status of the implementation of cooperation enterprises. In the stable culture and art market, the school take the initiative to find a variety of forms of schoolenterprise cooperation, long-term cooperation and short-term training, the nature of cooperation by the common interests, "learn from each other" cooperation, the implementation of multi-channel full cooperation. To provide students with a wide range of training, performance training opportunities, earlier in the arts on the road to grow up.

\section{A. Clear Cooperation Goals}

School participation in "school-enterprise cooperation" has two main objectives, on the one hand is to cultivate the social and economic development of the necessary music talent, on the other hand can improve the school's strength and school characteristics. Enterprises to participate in "school-enterprise cooperation" both to strengthen the core competitiveness of enterprises, but also to obtain the necessary talent to improve competitiveness. The cooperation between the two play a pivotal role is the students, students through the "school-enterprise cooperation" to improve the practical ability to improve the competitiveness of employment, through participation in practice can get a certain economic benefits. Hainan International Tourism Island colleges and universities need to be combined with regional culture, and regional enterprises to interact with each other in the clear objectives of cooperation in the "school-enterprise cooperation" to achieve the "tripartite victory" effect.

\section{B. Establish The Mode Of Cooperation}

First, the performing arts company or the theater can be used as a practice base for music performance professionals. And arrange excellent old staff to teach interns, all-round on the interns to work guidance, so that schools and enterprises to form a common education, management and training student's model. Second, the organization of senior experts regularly to the school every year to pre-school lectures. For the music show professional bring the latest knowledge and information, and to guide the reform of music practice courses, participate in music performance professional training program development. Such as Hainan Tropical
Ocean University invited the Hainan Provincial Folk Song and Dance Troupe experts and artists to teach students to teach, to cultivate ethnic minority local characteristics of music talent to meet the needs of the music talent in Hainan. Third, the school to accept the retraining of enterprise workers, to school to continue learning, training methods. And with the relevant functional departments for enterprises to provide staff to provide professional qualification certificate series. Fourth, the school encourages and supports students to join the chain of arts training institutions and enterprises in the policy to allow the development of music performance and training industries. Not only to provide professional knowledge, industry skills guidance, but also to provide theoretical knowledge and ideological guidance to ensure that students with the lowest risk to enter the market, enterprises in the most familiar way to operate the industry.

And cultural and art market to lead the art of high-level art troupe to establish cooperative relations. Hainan Tropical Ocean University, for example, with the Hainan Provincial Folk Song and Dance Troupe established a school-enterprise cooperation model, Hainan National Song and Dance Troupe is a professional art group, itself is also seeking to improve the source of funds to increase the lack of equipment, our hospital With its common interests, in 2014 formally merged with my school, through the "strong combination" art teacher resources and technology integration, to achieve a win-win situation. Training base in the school, outside the combination. Completed the "build base" "co-education talent" goal.

At the same time, Hainan Tropical Ocean University and the military, farm business sector to establish temporary performance, training, long-term cooperative relations, commitment to local performances of some major activities to enable students to exercise, and expand our college's social influence.

\section{Development Cooperation Project}

Hainan International Tourism Island University development faces many challenges and opportunities, both the coastal areas of regional resources, there are ethnic minority areas of regional cultural characteristics. Music professional development can be fully combined with national cultural resources, such as learning Qiong opera, $\mathrm{Li}$ folk songs, chord playing, Miao Lusheng playing, fire dance and other national dance, performance talent to learn these resources can be applied to national characteristics activities. Many ethnic traditional cultural festivals such as "March 3" and so on need a lot of talent showers; tourist attractions of various attractions with the National Tourism Festival to carry out the activities of the music needs of the national performance talent is also in short supply, such as "Happy Festival"; Ethnic areas of the opera groups, song and dance troupe also need national characteristics of music talent. The construction of these music culture and the cultivation of music talents can improve the influence and competitiveness of Hainan international tourism island at home and abroad. 


\section{SUMMARY}

School-enterprise cooperation has become an important educational characteristics of the application of technical colleges and universities, and Hainan International Tourism Island University music performance professionals are relatively lacking, the reason is mainly teaching units of school-enterprise cooperation in music teaching professional lack of correct Guidance and understanding. Music professional "school-enterprise cooperation" should be clear cooperation goals, establish cooperation, development of cooperation projects to broaden the school-enterprise cooperation greater possibilities and space.

\section{ACKNOWLEDGMENT}

This research was financially supported by the 2015 Hainan Education Science Research Topics of the 12th FiveYear Plan (No.QJY1251536); 2017 Education and Teaching Reform Project of Hainan Tropical Ocean University (No.RDJGb2017-39).

\section{REFERENCES}

[1] L.W. Yang, "Research on Talent Cultivation Model of Practical Teaching of Music Performance Specialty and Regional Cultural Linkage in Colleges and Universities," Journal of Zhejiang Institute of Media \& Communications, No. 05, 2011, pp.121-123.

[2] W. Ma, "Research on the Problems and Countermeasures in the Training Mode of Music Talents," Journal of Nanchang Normal University, vol. 35, No. 04, 2014, pp. 73-76.

[3] Y. Su, "Talking about the Importance of "Combination of Work and Study, School - Enterprise Cooperation" in Higher Vocational Music Education," Research on Higher Vocational Education of Land and Resources, No. Z1, 2008, pp.144-146.

[4] K. Zhang, H.X. Wang, H.F. Wang, Z. Li, "The Time Series Prediction Algorithm of Enrollment based on the Hesitancy degree Correction Rule of Vague Sets," ICIC Express Letters, vol. 09, No. 05, 2015, pp.1311-1318.

[5] J.Y. Shi, "Talking about the Importance of 'Combination of Work and Study, School - Enterprise Cooperation' in Higher Vocational Music Education," Cultural and educational materials, No. 23, 2007, pp.36-37.

[6] T.D. Si, W.J. Zhang, "The Reform and Practice of the Training Mode of Professional Talents for Performing Arts - Taking the Cultivation of Music Talents as an Example," Art Education, No. 03, 2015, pp.132-133.

[7] D.N. Zhou, "On the Present Situation and Prospect of Music Performance Education and Market Connection in Colleges and Universities," Music Magazine, No. 08, 2014, pp.213.

[8] K. Zhang, "The Application of Computer Personnel Training Practice Teaching Research in Colleges and Universities—-Take Qiongzhou University as an Example," Journal of Qiongzhou University, vol. 19, No. 02, 2012, pp.94-96.

[9] J. Zhu, "Study on the Music Culture Inheritance and Development of the Minorities Living on the Side between Hainan and Taiwan," The Border Economy and Culture, No. 01, 2014, pp.166-167.

[10] R.X. Chai, "Research on the Application of School - enterprise Cooperation in Music Specialty in Higher Vocational Colleges," Intelligence, No. 31, 2011, pp.256.

[11] J. Zhu, "Teaching Innovation Method of Music Performance Major in Colleges and Universities," DEStech Publications, Inc. In: 2016 3rd International Conference on Advanced Education Technology and Management Science (AETMS2016), January 24-25, 2016, Bangkok, Thailand, pp 385-387.
[12] L.R. Pan, "On the Construction of Talent Cultivation Model of Music Performance in Teachers Colleges," Journal of Jiangxi Institute of Education, vol. 30, No. 04, 2009, pp.42-44.

[13] J. Zhu, "The research and practice of the training mode of local university music performance professionals," Advances in Intelligent Systems Research., vol. 129, 2016, pp. 285-290.

[14] X.L. Lei, "Relying on the Mode of Cultivating Innovative Applied Talents for Professional School - Enterprise Cooperation Alliance," Art Education, No. 01, 2013, pp.52-53.

[15] J. Zhu, "Research on the Mode of Cooperation between School and Enterprise in Local University Music Performance Talents Training," Art Education, No. 02, 2016, pp.289.

[16] Y.X. Wu, C.W. Wang, "Relying on the Mode of Cultivating Innovative Applied Talents for Professional School - Enterprise Cooperation Alliance," China University Teaching, No. 09, 2012, pp.75-77.

[17] Y.F. Shen, "Innovation and Practice of Cultivating Model of Applied Talents in Music Performance," Journal of Tianzhong, vol. 31, No. 05, 2016, pp.126-128.

[18] J. Zhu, "The Construction of Specialized Teaching System of Musical Performance in Local Colleges and Universities," Teaching and Education (Higher Education Forum), vol. 18, No. 18, 2016, pp.84-85.

[19] N. Dang, Y.C. Chen, "The Construction of Specialized Teaching System of Musical Performance in Local Colleges and Universities," Continue Education Research, No. 02, 2013, pp.127-129.

[20] X.L. Liao, "Reform and Practice of Talent Cultivation Model of University - Enterprise Cooperation in University Music Performance," Song of the Yellow River, No. 09, 2015, pp.9.

[21] N. Gu, "A Probe into the Training Mode of Music Performance in Colleges and Universities from the Perspective of School - enterprise Cooperation," China Adult Education, No. 24, 2016, pp.87-89.

[22] X.P. Ba, "Practice and Exploration on the Cultivation of Talents of Music Performance in 'School - Enterprise Cooperation'," National Music, No. 04, 2011, pp.123-124.

[23] Z.D. Xiao, Y. Juan, "Analysis on the Cooperation between School and Enterprise of Music Performance Specialty in Universities in Beibu Gulf," Journal of Qinzhou University, No. 03, 2016, pp.86-69. 